\title{
ANALISIS STRATEGI BMT DALAM MENGHADAPI TRADE OFF ANTARA LIKUIDITAS DAN PROFITABILITAS
}

\author{
Irsad Andriyanto \\ Sekolah Tinggi Agama Islam Negeri Kudus \\ (irsad.smg@gmail.com)
}

Muzawida

\begin{abstract}
BMT juga mengalami konflik kepentingan (conflict of interest) antara liquidity dan profitability. Artinya bila BMT ingin mempertahankan posisi likuiditas dengan memperbesar cadangan kas, maka BMT tidak akan memakai seluruh loanable funds (dana yang telah dihimpun dari masyarakat) yang ada karena sebagian akan dikembalikan lagi dalam bentuk cadangan tunai (cash reserve). Hal ini berarti upaya pencapaian rentabilitas (profitability) akan berkurang. Demikian juga terjadi sebaliknya. Tujuan penilitian ini meliputi: 1) menganalisis tingkat likuiditas BMT. 2) menganalisis tingkat profitabilitas pada BMT. 3) menganalisis strategi yang diterapkan BMT dalam menghadapi trade off antara likuiditas dan profitabilitas.

Hasil penilitian menunjukkan bahwa: 1) Dari tahun 2010 hingga 2013 tingkat likuiditas ditinjau dari cash ratio rata-rata masuk dalam kategori cukup likuid. 2)Tingkat profitabilitas ditinjau dari Return On Asset masuk dalam kategori rendah. Rendahnya tingkat profitabilitas ini salah satunya disebabkan karena tingginya tingkat likuiditas. 3) Dalam pengelolaan dana likuiditas dan profitabilitas, BMT menggunakan manajemen dengan pendekatan pool of fund approach. Semua dana BMT yang bersumber dari berbagai pihak dengan berbagai macam akad dikumpulkan ke dalam satu wadah, kemudian manajemen BMT dapat dengan bebas mengalokasikan ke dalam berbagai bentuk pembiayaan yang tidak dibatasi oleh akad yang berbeda-beda baik akad yang memiliki hasil maupun tidak.
\end{abstract}

Kata Kunci: profitabilitas, likuiditas, trade off

\section{A. Latar Belakang}

Dalam kehidupan masyarakat yang semakin modern, masyarakat semakin dituntut untuk memperhatikan kebutuhan hidup dimasa mendatang mengingat adanya ketidakpastian yang semakin meningkat yang terjadi karena berbagai faktor ekonomi dan nonekonomi. Ketidakpastian dimasa mendatang harus diantisipasi 
dengan tindakan berjaga-jaga dimasa sekarang ini, diantaranya dengan mengalokasikan sebagian pendapatan yang tidak digunakan untuk konsumsi, yaitu untuk menabung.

Pengalokasian sebagian pendapatan untuk pengeluaran tabungan dapat dilakukan dengan cara menyimpan uang tunai di lembaga keuangan konvensional maupun syariah. Lembaga keuangan syariah adalah bagian sistem perbankan yang pelaksanaanya berdasarkan hukum Islam. Lembaga keuangan syariah ada yang merupakan lembaga bank dan lembaga non bank.

BMT adalah lembaga keuangan non bank sebagai balai usaha mandiri terpadu yang merupakan bayt al-mal wa at-tamwil, yaitu lembaga yang mengembangkan usahausaha produktif dan investasi untuk meningkatkan kualitas usaha para pengusaha kecil dan mendorong bentuk- bentuk investasi dengan tujuan pemberdayaan usaha duniawi dan ukhrawi melalui infak, zakat dan sedekah. BMT merupakan Lembaga Keuangan Syariah nonperbankan yang bersifat informal. ${ }^{1}$ Dalam diskursus ekonomi Islam BMT dapat pula dikategorikan dengan koperasi syariah, yaitu lembaga ekonomi yang berfungsi untuk menarik, mengelola, dan menyalurkan dana dari, oleh, dan untuk masyarakat.

Return on asset merupakan bagian dari rasio profitabilitas, yakni merupakan salah satu pengukur kinerja keuangan sebuah perbankan. Perbankan yang mempunyai profitabilitas bagus maka kelangsungan hidup bank tersebut akan terjamin. Namun sebaliknya jika bank mempunyai profitabilitas buruk maka kelangsungan hidup bank tidak akan bertahan lama, karena bank tersebut tidak mampu untuk memenuhi biaya-biaya operasional. Selain itu minimnya tingkat profitabilitas juga akan berdampak pada sulitnya bank untuk mengembankan usahanya. Salah satu faktor yang mempengaruhi tinggi rendahnya sebuah profitabilitas dalam perbankan adalah likuiditas. Likuiditas menunjukkan kemampuan suatu perusahaan untuk memenuhi kewajiban keuangannya yang harus segera dipenuhi, atau kemampuan perusahaan untuk memenuhi kewajiban keuangan pada saat ditagih. Perusahaan yang mampu memenuhi kewajiban tepat pada waktunya berarti perusahaan tersebut dalam keadaan likuid, sebaliknya apabila perusahaan tidak dapat segera memenuhi kewajiban keuangannya pada saat ditagih, berarti perusahaan tersebut dalam keadaan ilikuid. $^{2}$

Pada perbankan selalu timbul pertentangan kepentingan (conflik of interest) antara liquidity dan profitability. Artinya bila bank mempertahankan posisi likuiditas dengan memperbesar cadangan kas, maka bank tidak akan memakai seluruh loanable funds

\footnotetext{
${ }^{1}$ Ahmad Hasan Ridwan, Manajemen Baitul Mal wa Tamwil, Bandung; CV PUSTAKA SETIA, 2013, hlm. v

${ }^{2}$ Munawir, Analisis Laporan Keuangan, Yogyakarta; Liberty, 2012, hlm.31
} 
(dana yang telah dihimpun dari masyarakat) yang ada karena sebagian dikembalikan lagi dalam bentuk cadangan tunai (cash reserve) dan ini berarti upaya pencapaian rentabilitas (profitability) akan berkurang. Sebaliknya jika ingin memeprtinggi rentabilitas maka sebagian cash reserve (cadangan tunai) untuk likuiditas terpakai oleh bisnis bank, sehingga posisi likuiditas akan turun di bawah minimum. Dengan kata lain, bila bank menginginkan profitabilitas yang tinggi maka tingkat likuiditas akan berkurang, dan begitupun sebaliknya. ${ }^{3}$ Berdasarkan kenyataan tersebut, maka bank harus mempetimbangkan trade-off antara likuiditas dan profitabilitasnya.

Gambaran di atas menunjukkan, hubungan antara likuiditas dan profitabilitas merupakan hubungan yang saling mempengaruhi, dan biasanya terjadi trade-off (tarik ulur). Dengan kata lain, jika likuiditas tinggi maka profitabilitas bank akan rendah, namun jika likuiditas rendah maka profitabilitas bank akan tinggi.

\section{B. Likuiditas}

\section{a) Pengertian likuiditas}

Likuiditas adalah suatu istilah yang dipakai untuk menunjukkan suatu persediaan uang tunai dan asset lain yang dengan mudah dijadikan uang tunai. Likuiditas adalah kemampuan bank untuk memenuhi semua penarikan dana oleh nasabah, deposan, kewajiban yang telah jatuh tempo, dan memenuhi permintaan kredit tanpa penundaan. Bank dianggap likuid apabila bank tersebut mempunyai cukup uang tunai atau asset likuid lainya, disertai kemampuan untuk meningkatkan jumlah dana dengan cepat dari sumber lainya, memungkinkanya memenuhi kewajiban pembayaran dan komitmen keuangan lain pada saat yang tepat. Jadi yang dimaksud likuiditas adalah suatu keadaan yang berhubungan dengan persediaan uang tunai dan alat-alat likuid lainya yang dikuasai bank yang bersangkutan. ${ }^{4}$

Suatu perusahaan yang ingin mempertahankan kelangsungan kegiatan usahanya harus memiliki kemampuan untuk melunasi kewajiban-kewajiban finansial yang segera dilunasi. Dengan demikian likuiditas merupakan indikator kemampuan perusahaan untuk membayar atau melunasi kewajiban-kewajiban finansialnya pada saat jatuh tempo dengan mempergunakan aktiva lancar yang tersedia. ${ }^{5}$

Likuiditas suatu bank mempunyai peranan penting dalam keberhasilan pengelolaan bank. Likuiditas diperlukan antara lain untuk keperluan:

\footnotetext{
${ }^{3}$ Muhammmad, Manajemen dana Bank Syariah, Yogyakarta; EKONISIA, 2004, hlm. 63

${ }^{4}$ Herman Darmawi, Manajemen Perbankkan, Bumi Aksara, cetakan ke-1, Jakarta, 2011, hlm.: 59.

${ }^{5}$ Siti Amaroh, Manajemen Keuangan (Buku Daros), Kudus, 2008, hlm. 33
} 
1. Pemenuhan aturan reserve requirement atau cadangan wajib minimum yang diterapkan oleh bank sentral.

2. Penarikan dana oleh deposan

3. Penarikan dana oleh debitor.

4. Pembayaran kewajiban yang jatuh tempo. Suatu bank dianggap likuid apabila;

a. Mempunyai sejumlah alat likuid yang dapat memenuhi kebutuhan likuiditasnya sesuai dengan waktunya.

b. Mampu memperoleh tambahan alat likuid sesuai kebutuhan dengan berbagai macam cara seperti melalui pinjaman, penjualan saham, penyetoran modal dan korversi dari asset yang likuiditasnya rendah menjadi alat-alat likuid.

\section{b) Manajemen likuiditas.}

Manajemen likuiditas adalah menyangkut pemikiran kebutuhan dan penyediaan kas secara terus menerus baik kebutuhan jangka pendek, musiman maupun jangka panjang. 6 Tujuan jangka panjang bank adalah mendapatkan keuntungan. Keuntungan diperoleh jika bank dikelola dengan manajemen yang tepat. Secara umum pengelolaan keuangan perusahaan akan menghadapi tiga masalah yang penting yaitu likuiditas, solvabilitas dan rentabilitas.

Untuk menjaga posisi perusahaan agar tetap likuid, perusahaan harus mengelola likuiditasnya dengan cara yang benar. Likuiditas bagi bank merupakan masalah yang sangat penting karena berkaitan dengan kepercayaan masyarakat, nasabah, dan pemerintah. Dalam dunia perbankan sering timbul pertentangan antara likuiditas dengan profitabilitas. Untuk mempertahankan posisi likuiditas yang tinggi berarti harus menggunakan dana yang seharusnya biasa dipinjamkan untuk memperbesar cadangan primer. Dengan demikian maka kesempatan untuk mendapatkan keuntungan akan berkurang. Pengelolaan likuditas dapat dilakukan dengan dua pendekatan:

a. Asset Management

Asset managemen (pengelolaan kekayaan) adalah pengelolaan kekayaan yang digunakan untuk alokasi dana/kekayaan untuk berbagai alternatif investasi.

b. Liability management

Liability managemen (pengelolaan utang) adalah suatu proses dimana bank berusaha mengembangkan sumber-sumber dana yang nontradisional melalui pinjaman di pasar uang atau dengan menerbitkan instrument utang untuk digunakan secara menguntungkan terutama untuk memenuhi permintaan

\footnotetext{
${ }^{6}$ M. Suhan \& Ely Siswanto, Manajemen Bank Konvensional \& Syariah, UIN Malang Press (Anggota IKAPI), Malang, 2008, hlm: 98
} 
kredit. Pemenuhan likuiditas melalui sumber-sumber nontradisional seperti pinjaman antar bank, penjualan sertifikat deposito, penerbitan surat berharga di pasar uang, rephuchase agreement, dan euro dollar. ${ }^{7}$

Tujuan manajemen likuiditas adalah :

a. Menjaga posisi likuiditas agar selalu berada pada posisi yang ditentukan oleh otoritas moneter.

b. Mengelola alat-alat likuid agar selalu dapat memenuhi semua kebutuhan cash flow termasuk kebutuhan yang tidak dipekirakan.

c. Memperkecil terjadinya dana menganggur (idle fund)

d. Menjaga posisi likuiditas dan proyeksi cash flow selalu dalam posisi aman terutama dalam tingkat bunga yang berfluktuasi ${ }^{8}$

Keberhasilan bank dalam manajemen likuiditas dapat diketahui pada:

a. Kemampuan memprediksi kebutuhan dana di waktu yang akan datang.

b. Kemampuan untuk memenuhi permintaan akan cash dengan menukarkan harta lancarnya.

c. Kemampuan memperoleh cash secara mudah dengan biaya yang sedikit.

d. Kemampuan pendapatan pergerakan cash in dan cash out dana (cash flow)

e. Kemampuan untuk memenuhi kewajibanya tanpa harus mencairkan aktiva tetap apapun kedalam cash.

\section{c) Strategi memelihara likuiditas.}

Beberapa strategi yang dapat diterapkan oleh bank dalam memelihara likuiditasnya tidak lepas dari fungsi bank sebagai lembaga intermediasi keuangan. Strategi tersebut antara lain:

a. Memperpanjang jatuh tempo semua kewajiban bank, kecuali jika tingkat suku bunga cenderung menurun.

b. Melakukan diversifikasi sumber dana bank dengan menggali sumber dana dengan melakukan penjualan produk pasiva lainya yang beragam.

c. Menjaga keseimbangan jangka waktu asset dan kewajiban dengan cara koordinasi rutin dengan unit kerja marketing, treasury dan pengkreditan dalam rapat ALCO (assets liability committee). Koordinator ini diperlukan untuk memantau jumlah kebutuhan dana untuk komitmen kredit, berapa lama jangka waktunya dan sebagaimana sehingga dapat dirancang sumber dana yang sesuai jangka waktu dan komitmen kredit tersebut.

\footnotetext{
${ }^{7}$ Subagyo, Bank dan Lembaga Keungan Lainya, Edisi ke-2, Cetakan Pertama, Sekolah Tinggi Ilmu Ekonomi YKPN, Yogyakarta, 2002, hlm: 90-92

${ }^{8}$ M.suhan \& Ely siswanto, Op Cit, hlm: 98
} 
d. Memperbaiki likuiditas dengan mengalihkan asset yang kurang marketable dengan asset yang lebih marketable.

\section{d) Analisis rasio likuiditas.}

Analisis rasio likuiditas adalah analisis yang dilakukan terhadap kemampuan bank dalam memenuhi kewajiban-kewajiban jangka pendeknya atau kewajiban yang sudah jatuh tempo. Rasio-rasio likuiditas pada prinsipnya bertujuan untuk membantu perusahaan mengetahui kemampuan modal yang bekerja sejalan dengan aktivitas perusahaan agar selalu dalam posisi siap digunakan untuk membayar kewajiban atau hutang jangka pendeknya.

Berikut adalah rasio-rasio likuiditas:

a. Rasio Kas (Cash ratio)

Rasio ini menunjukkan tingkat keamampuan peusahaan untuk membayar hutang-hutang jangka pendek dengan melihat jumlah kas dan bank yang dimiliki perusahaan. Dengan kata lain cash ratio adalah perbandingan antara alat likuid dengan hutang lancar.

Alat likuid terdiri atas:

- Kas

- Giro, tabungan, deposito di bank syariah atau koperasi syariah lainya.

Hutang lancar terdiri dari:

- Kewajiban segera

- Simpanan wadiah

- Simpanan berjangka

Tabel 1. Kriteria Penilaian Likuiditas Cash Ratio

\begin{tabular}{|c|c|}
\hline Rasio kas $\%$ & Kriteria \\
\hline$<14$ dan $>56$ & Tidak likuid \\
\hline$(14-20)$ dan $(46-56)$ & Kurang likuid \\
\hline$(21-25)$ dan $(35-45)$ & Cukup likuid \\
\hline$(26-34)$ & Likuid \\
\hline
\end{tabular}

Sumber: Permen Koperasi Dan Usaha Kecil Dan Menengah Republik Indonesia Nomor : 35.3/Per/M.KUKM/X/2007 Tentang Pedoman Penilaian Kesehatan Koperasi jasa keuangan syariah dan unit jasa keuangan syariah koperasi.

b. Rasio Pinjaman Terhadap Dana Yang Diterima (Loan to Deposit Ratio) 
Merupakan alat ukur rasio likuiditas yang mengukur sejauhmana besarnya utang dapat ditutupi oleh modal. Rasio ini menunjukkan komposisi atau struktur modal dari total utang terhadap total modal yang dimiliki perusahaan.

Tabel 2 Kriteria Penilaian Likuiditas FDR

\begin{tabular}{|c|c|}
\hline Rasio pembiayaan $\%$ & Kriteria \\
\hline$<50$ & Tidak likuid \\
\hline $51-75$ & Kurang likuid \\
\hline $76-100$ & Cukup likuid \\
\hline$>100$ & Likuid \\
\hline
\end{tabular}

Sumber: Permen Koperasi Dan Usaha Kecil Dan Menengah Republik Indonesia Nomor : 35.3/Per/M.KUKM/X/2007 Tentang Pedoman Penilaian Kesehatan Koperasi jasa keuangan syariah dan unit jasa keuangan syariah koperasi.

\section{Profitabilitas}

\section{1) Pengertian Profitabilitas.}

Profit adalah kelebihan harga jual atas harga pokok atau dalam suatu perusahaan secara keseluruhan merupakan kelebihan pendapatan atas seluruh beban. ${ }^{9}$ Pada umumnya profitabilitas suatu perusahaan menunjukkan perbandingan aktiva laba yang diperoleh dalam operasi perusahaan dengan aktiva atau modal. Profitabilitas merupakan suatu kemampuan bank dalam menghasilkan laba selama periode tertentu. ${ }^{10}$

Profitabilitas sering disebut juga dengan rentabilitas. Bank yang sehat adalah bank yang diukur secara profitabilitas atau rentabilitas yang terus meningkat di atas standar yang diterapkan.

Sedangkan rasio profitabilitas adalah alat untuk menganalisa atau alat untuk mengukur tingkat efisiensi usaha dan profitabilitas yang dicapai oleh bank yang bersangkutan. Profitabilitas sering digunakan untuk mengukur efisiensi penggunaan modal dalam suatu perusahaan yaitu dengan modal yang digunakan operasi perusahaan.

Rasio digunakan untuk mengukur kemampuan perusahaan menghasilkan keuntungan pada tingkat penjualan, asset, dan modal saham tertentu. ${ }^{11}$ Cara untuk

\footnotetext{
${ }^{9}$ Ivan Rohmawan, Kamus Istilah Akuntansi Syariah, Nuansa Aksara, Yogyakarta, 2005, hlm: 226

${ }^{10}$ Munawir, Analisis Lapran keuangan, Lliberty, Yogyakarta, 2012, hlm: 33

${ }^{11}$ Mahmud M.Hanafi, Abdul Halim, Analisis Laporan Keuangan, UPP,STIM YKPN, Yogyakarta, 2007,hlm: 81
} 
menilai profitabilitas suatu perusahaan bermacam- macam dan tergantung pula pada modal mana yang akan diperbandingkan satu dengan yang lainya. Dengan adanya bermacam- macam cara penilaian profitabilitas suatu perusahaan yang berbeda dalam cara menghitung profitabilitas perusahaan maka tidak mengherankan kalau ada beberapa perusahaan yang berbeda dalam cara menghitung profitabilitas yang penting rasio profitabilitas mana yang akan digunakan sebagai pengukur efisiensi penggunaan modal yang bersangkutan untuk menghasilkan laba.

\section{2) Analisis Rasio Profitabilitas.}

Analisis rasio profitabilitas bank adalah alat untuk menganalisis atau mengukur tingkat efisiensi usaha dan profitabilitas yang dicapai oleh bank yang bersangkutan. Rasio keuntungan (profitability ratio) atau rentabilitas yaitu rasio yang menunjukkan kemampuan perusahaan untuk memperoleh keuntungan dari penggunaan modalnya. ${ }^{12}$

Rasio profitabilitas menggambarkan kemampuan perusahaan mendapatkan laba melalui semua kemampuan, dan sumber yang ada seperti kegiatan penjualan, kas, modal, jumlah karyawan, jumlah cabang dan sebagainya. ${ }^{13}$

Berikut ini adalah rasio-rasio profitabilitas:

a. Return On Assets (ROA)

Return On Asset (ROA) adalah rasio yang menggambarkan kemampuan bank dalam mengelola dana yang diinventariskan dalam keseluruhan asset yang menghasilkan keuntungan. ROA adalah gambaran produktifitas bank dalam mengelola dana sehingga menghasilkan keuntungan.

Rasio ini digunakan untuk mengukur kemampuan manajemen bank dalam memperoleh keuntungan (laba) secara keseluruhan. Semakin besar ROA suatu bank, semakin besar pula tingkat keuntungan yang dicapai bank tersebut dan semakin baik pula posisi bank tersebut dari segi penggunaan asset.

Tabel 3. Kriteria Penilaian untuk Return On Assets (ROA)

\begin{tabular}{|c|c|}
\hline Rasio Rentabilitas Asset \% & Kriteria \\
\hline$<5 \%$ & Kurang baik \\
\hline $5-7,4$ & Cukup baik \\
\hline $7,5-10$ & Baik \\
\hline
\end{tabular}

\footnotetext{
${ }^{12}$ Siti amaroh, Op Cit, hlm. 31

${ }^{13}$ Muhammad Syafi'I Antonio, Bank Syariah Dari Teori Ke Praktek, Gema Insani Press, Jakarta, 2001, hlm: 205
} 


\section{\begin{tabular}{|l|l|}
\hline$>10$ & Sangat Baik \\
\hline
\end{tabular}}

Sumber: Permen Koperasi Dan Usaha Kecil Dan Menengah Republik Indonesia Nomor : 35.3/Per/M.KUKM/X/2007 Tentang Pedoman Penilaian Kesehatan Koperasi jasa keuangan syariah dan unit jasa keuangan syariah koperasi.

b. Rentabilitas modal sendiri.

Rentabilitas modal sendiri atau sering juga dinamakan rentabilitas usaha adalah perbandingan jumlah laba yang tersedia bagi pemilik modal sendiri di satu pihak dengan jumlah modal sendiri yang menghasilkan laba tersebut di lain pihak atau dengan kata lain rentabilitas modal sendiri adalah kemampuan suatu perusahaan dengan modal sendiri yang berkerja di dalamnya untuk menghasilkan keuntungan.

Tabel 4. Kriteria Penilaian untuk Rentabilitas Modal Sendiri

\begin{tabular}{|c|c|}
\hline Rasio Rentabilitas Ekuitas & Kritera \\
\hline$<5 \%$ & Rendah \\
\hline $5-7,4$ & Kurang \\
\hline $7,5-10$ & Cukup \\
\hline$>10$ & Tinggi \\
\hline
\end{tabular}

Sumber: Permen Koperasi Dan Usaha Kecil Dan Menengah Republik Indonesia Nomor : 35.3/Per/M.KUKM/X/2007 Tentang Pedoman Penilaian Kesehatan Koperasi jasa keuangan syariah dan unit jasa keuangan syariah koperasi.

c. Rasio Kemandirian Operasional

Yaitu pendapatan usaha dibandingkan dengan biaya operasional.

Tabel 5 Kriteria Penilaian untuk kemandirian operasional

\begin{tabular}{|c|c|}
\hline Rasio Kemandirian Operasional & Kriteria \\
\hline$<100$ & Rendah \\
\hline $100-125$ & Kurang \\
\hline $126-150$ & Cukup \\
\hline$\square 150$ & Tinggi \\
\hline
\end{tabular}

Sumber: Permen Koperasi Dan Usaha Kecil Dan Menengah Republik Indonesia Nomor : 35.3/Per/M.KUKM/X/2007 Tentang Pedoman Penilaian Kesehatan Koperasi jasa keuangan syariah dan unit jasa keuangan syariah koperasi. 


\section{Hubungan Likuiditas Dengan Profitabilitas.}

Lembaga perbankan, termasuk bank syariah ataupun BMT didirikan sebagai lembaga intemediary yang berfungsi sebagai perantara pemilik dana dan pemakai dana. Dengan demikian bank adalah lembaga pengganti pemilik dana dan pemakai dana. Sebagai pemilik dana bank berkewajiban untuk membayar ke pemilik dana, apabila pemakai dana tidak melunasi kewajibannya dan peran sebagai pemakai dana adalah apabila pemilik dana menarik dananya sebelum jatuh tempo atau sebelum waktu yang ditentukan. Hal ini berarti bank harus selalu menjaga penarikan dana dari sumber dana yang dititipkan. ${ }^{14}$

Pengukuran likuiditas adalah pengukuran yang sangat dilematis, karena di satu sisi usaha bank utama adalah memasarkan dan atau memutar uang nasabahnya untuk mendapatkan keuntungan. Artinya bisnis perbankan harus memaksimalkan pemasaran uangnya dan sekecil mungkin mencegah uang menganggur (idle money). Disisi lain untuk dapat memenuhi kewajibanya terhadap para deposan dan debitur yang sewaktu- waktu menarik dananya dari bank, bank dituntut harus selalu dalam posisi siap membayar, yang artinya bank harus mempunyai cadangan uang menganggur yang cukup.

Keadaan ini merupakan dilema yang dihadapi oleh perbankan, karena antara kebutuhan likuiditas dan tingkat keuntungan yang akan dicapai mempunyai sisi yang bertolak belakang. Semakin tinggi likuiditas berarti semakin banyak uang yang menganggur, berarti pemasaran uang tidak maksimal dan artinya bank tidak bisa memaksimalkan keuntunganya. ${ }^{15}$

Dalam mengelola likuiditas, selalu akan terjadi benturan kepentingan antara keputusan untuk menjaga likuiditas dan meningkatkan pendapatan. Bank yang selalu berhati-hati menjaga likuiditas akan cenderung memelihara alat likuid yang relatif lebih besar dari yang diperlukanya dengan maksud untuk menghindari kesulitan likuiditas, namun di sisi lain bank juga dihadapkan pada biaya yang sangat besar berkaitan dengan pemeliharaan alat likuid yang berlebihan. Oleh karena itu, manajemen likuiditas perlu adanya keseimbangan antara dua kepentingan di atas.

\section{E. Strategi dalam menghadapi trade-off (tarik ulur) antara likuiditas dengan profitabilitas.}

Bank selalu dihadapkan pada dua pilihan yang saling bertentangan yaitu likuiditas dan profitabilitas. Jika bank lebih mengutamakan likuiditasnya

\footnotetext{
${ }^{14}$ Muhammad, Manajemen Dana Bank Syariah, EKONOSIA, Yogyakarta, 2004, hlm: 64

${ }^{15}$ Rimsky K. Judiseno, Sistem Moneter Dan Perbankan Di Indonesia, PT. Gramedia Pustaka Utama,, Jakarta, 2002, hlm: 138
} 
guna memelihara kepercayaan nasabah, bank akan kehilangan kesempatan untuk memperoleh laba yang diperoleh dari penyaluran dana ke aktiva produktif. Jika bank lebih mengutamakan profitabilitasnya berupa penyaluran dana pada aktiva produktif dan kurang memperhatikan likuiditas, maka bank tidak dapat memenuhi kewajiban penyediaan dana untuk penarikan dana nasabah sehari hari. Untuk itu bank perlu menerapkan strategi tetentu dalam menggunakan dananya agar kepentinganya terpenuhi.

Dalam manajemen aktiva pasiva, ada dua strategi yang dapat digunakan untuk mengatasi dilema likuiditas dan profitabilitas yaitu pool of fund approach dan asset allocation approach. ${ }^{16}$

a. Pool of fund approach.

Strategi pool of fund dilakukan dengan memperlakukan semua kewajiban bank yang berasal dari berbagai sumber sebagai dana tunggal tanpa membedakan sumber, bentuk dana maupun jangka waktu dan karakteristik-karakteristik lain dari dana tersebut secara individual. Dana ini kemudian dialokasikan berdasarkan prioritas penggunaan sesuai kebijakan dan strategi manajemen.

Pendekatan ini umumnya dianut oleh bank yang opearsionalnya berdasarkan prinsip Brach Banking System yaitu bank yang semua kebijakan pengelolaan dananya diatur oleh pusat sehingga biasanya dipusatkan pada kantor pusat.

Strategi pool of fund mempunyai kekuatan dan kelemahan, yaitu :

1. Kekuatan pola pendekatan pool of fund approach:

a) Tidak melihat asal usul sumber dana

b) Dana dimanfaatkan menurut skala prioritas

2. Kelemahan pola pendekatan pool of fund approach:

a) Tidak mempertimbangkan perubahan biaya dari berbagai sumber dana

b) Tidak mempertimbangkan ukuran standar likuiditas setiap bank.

\footnotetext{
${ }^{16}$ M. Sulhan \& Ely Siswanto, Manajemen Bank Konvensional \&Syariah, UIN-Malang Press (Anggota IKAPI), Malang, 2008, hlm: 93
} 


\section{Gambar 1}

Skema strategi pool of fund approach ${ }^{17}$

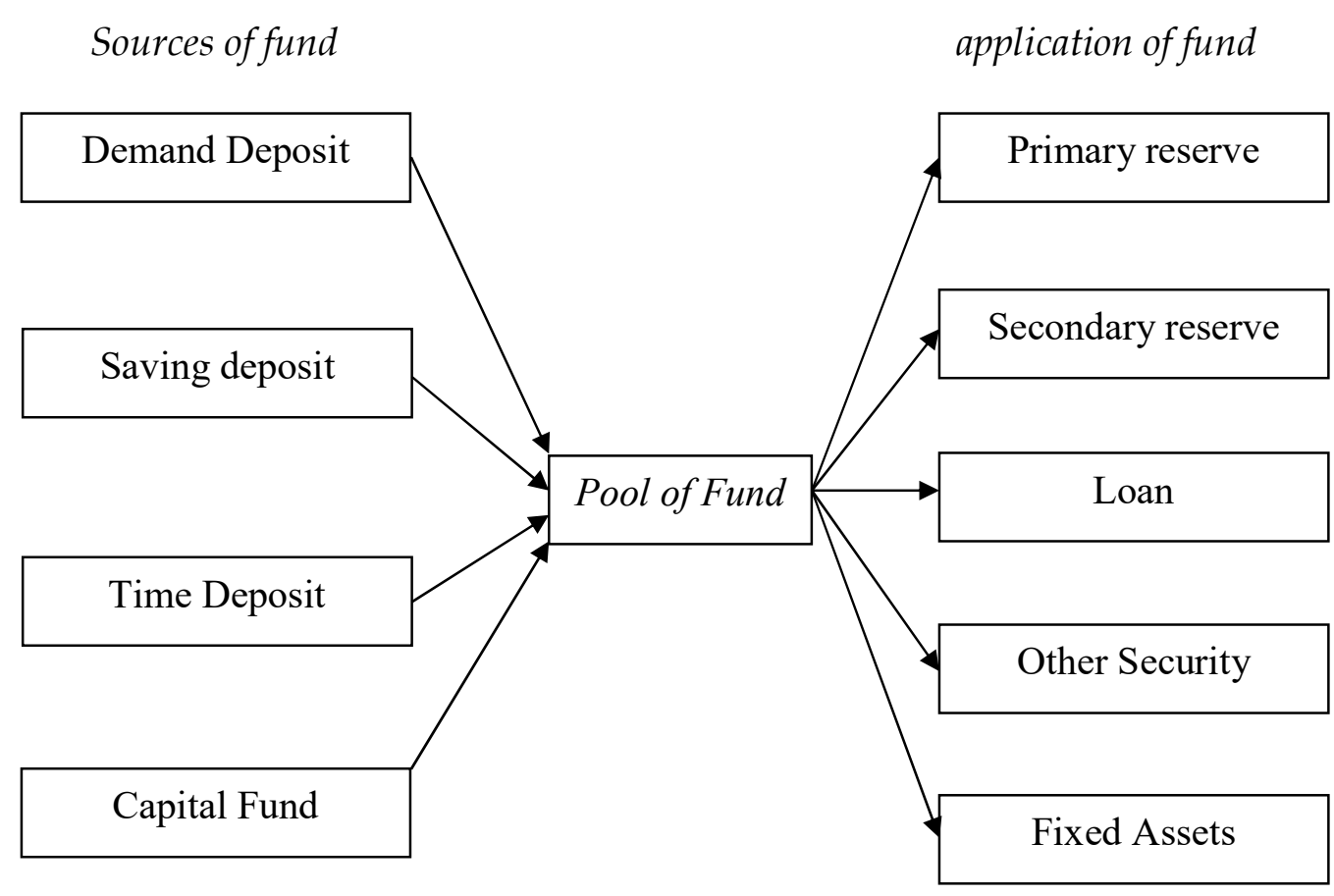

b. Asset allocation approach

Sebagai koreksi atas strategi pool of fund approach, strategi asset allocation approach pengalokasian dana bank harus diperlakukan secara individu dengan mempertimbangkan karakteristik sendiri-sendiri. Dana dengan sifat perputaan tinggi diprioritaskan dalam cadangan primer dan sekunder, sedangkan yang perputaranya rendah dapat diprioritaskan pada penyaluran kredit atau aktiva jangka panjang lainya.

Terdapat beberapa alternatif pengguanaan dana berdasarkan skala prioritasnya dapat digolongkan kedalam cadangan primer (primary reserve), cadangan sekunder (secondary reserve), cadangan tersier (tertiary reserve) atau kredit yang disalurkan (loan), quertery reserve atau investmen dan quinnary reserve atau fixed assaet.

Dana yang memiliki sifat perputaran yang cukup tinggi hendaknya penggunaannya diprioritaskan dalam cadangan primer dan sekunder, sedangkan dana yang perputaranya relatif rendah pengalokasiannya dapat diprioritaskan pada pos kredit yang diberikan dan aktiva jangka panjang lainya.

${ }^{17}$ Muchdarsyah Sinungan, Manajemen Dana Bank Edisi ke-2, PT. Bumi Aksara, Jakarta, 2000, hlm: 97 
Primery reserve adalah cadangan utama yang harus dipelihara oleh bank umum, demi memenuhi kepentingan likuiditas minimum berdasarkan ketentuan yuridis dari bank sentral dan kebutuhan operasional sehari hari seperti transaksi dengan bank koresponden, penarikan dana oleh masabah, permintaan kredit oleh masyarakat dan sebagainya.

Secondery reserve adalah cadangan tunai kedua yang berfungsi sebagai cadangan penyangga posisi primary reserve. Artinya, bila saldo kas terus berkurang, demikian juga dengan saldo giro pada Bank Indonesia sebagai akibat dari besarnya penarikan nasabah, maka secondary reserve akan muncul ke permukaan untuk emberikan bantuan. Bantuan secondary reserve ini akan dapat memperbaiki posisi likuiditas yang sudah mulai terancam. ${ }^{18}$ Secondary reserve umumnya ditanam dalam bentuk surat berharga jangka pendek dan berkualitas tinggi seperti Sertifikat Bank Indonesia (SBI) deposito (certificate of deposit/), promes (promissory note). Banker'acceptance (BA), Repo (repurchase agreement) dan commercial paper (CP).

Tertiary reserve atau prioritas ketiga pengalokasian dana adalah dalam bentuk pemberian kredit (loan). Pemberian kredit merupakan kegiatan utama bank dan merupakan sumber pendapatan utama bank. Commercial loan theory menyatakan bahwa kredit dapat dijadikan sumber likuiditas dari pembayaran angsuran yang dilakukan debitur.

Quartery reserve merupakan prioritas berikutnya dari penggunaan dana bank yang masih tersisa dan biasanya ditanamkan dalam bentuk surat surat berharga jangka panjang seperti obligasi baik obligasi pemerintah (government bond) maupun obligasi swasta (corporate bond). Kelebihan konsep ini adalah perhitungan biaya dana lebih relative sederhana dan pengalokasianya tiak kompleks. Kelemahan dari konsep ini adalah sulit memprediksi kebutuhan standar likuiditas.

Quinnarry reserve adalah penggunaan dana untuk pemebelian aktiva tetap. Aktiva tetap harus dibiayai dengan menggunakan modal sendiri. Jumlah modal yang dapat dialokasikan pada aktiva tetap dan inventaris haruslah tidak melebihi ketentuan bank Indonesia.

Kelebihan konsep asset allocation approach adalah pengalihan penekanan likuiditas dan profitabilitas. Pendekatan ini menjadikan jumlah rata-rata cadangan likuiditas yang dimiliki bank mengalami penurunan sehingga pengalokasian dana dapat dialihkan lebih besar pada penyaluran pembiayaan dan penanaman surat-surat berharga yang memiliki keuntungan lebih tinggi.

Kekuatan pola pendekatan Asset Allocation Approach adalah:

\footnotetext{
${ }^{18}$ Muchdarsyah Sinungan, Strategi Manajemen Bank Menghadapi Tahun 2000, PT. RINEKA CIPTA, Jakarta, 1994, hlm: 66
} 
- Cadangan likuiditas dapat dihitung lebih cermat sebagai dana yang dapat dialokasikan relative lebih besar.

- Pemanfaatan dana disesuaikan dengan karakteristik sumber dana.

Kelemahan pola pendekatan Asset Allocation Approach adalah:

- Sulit menghitung besarnya biaya dan alokasi

- Sering mencadangkan likuiditas berlebih sebagai cara mengantisipasi perilaku nasabah. 


\section{Gambar 2}

Skema strategi assets allocation approach ${ }^{19}$

\section{SOURCES OF FUND $\quad$ USES OF FUND}

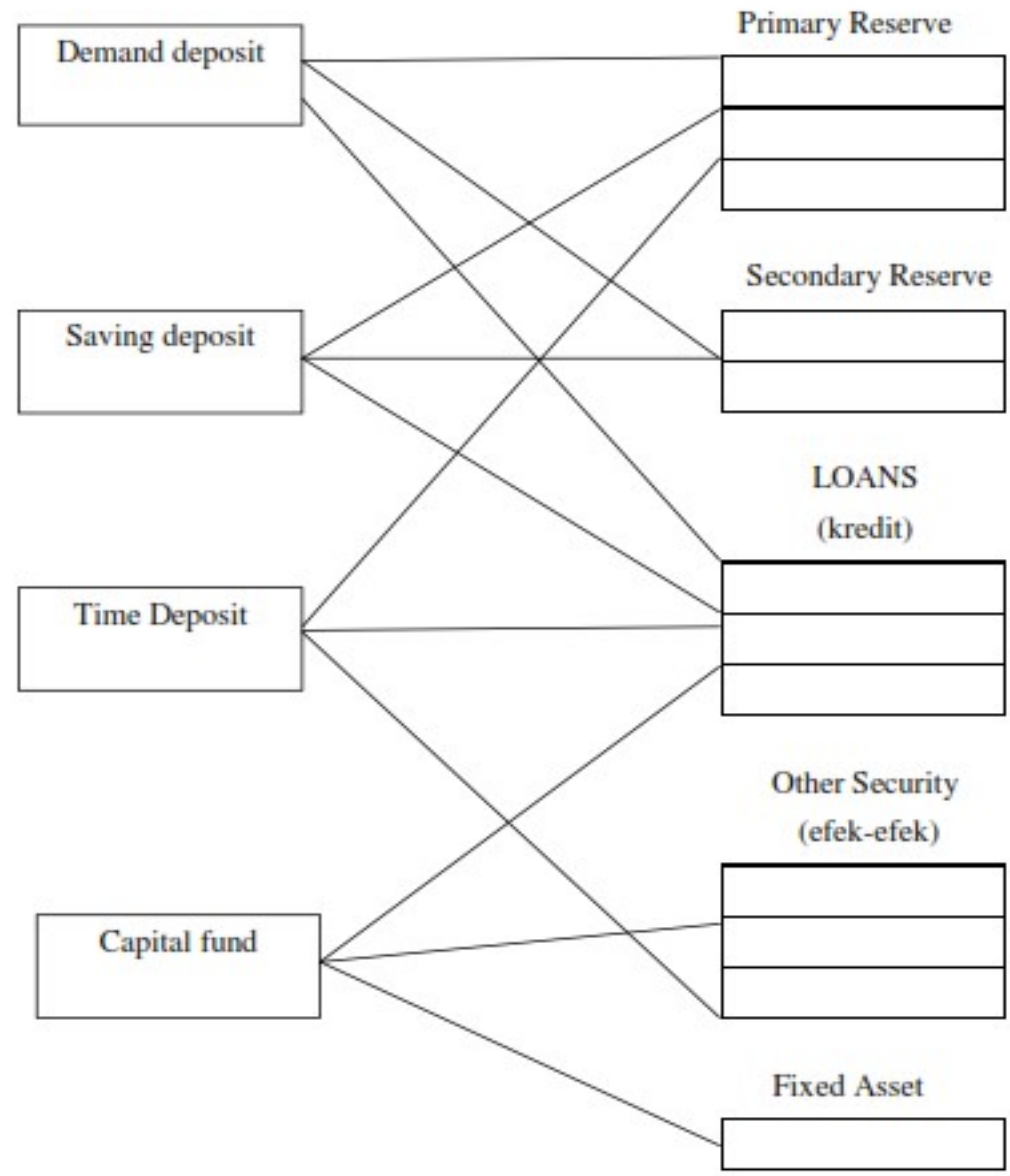

\section{F. Analisis Strategi Dalam Menghadapi Trade Off Antara Likuiditas Dan Profitabilitas Pada BMT}

Trade off adalah istilah yang digunakan dalam perbankan yang menggambarkan pertentangan kepentingan antara likuiditas dan profitabilitas. Dalam menghadapi trade off antara likuiditas dan profitabilitasnya BMT dapat memilih antara menggunakan dengan pendekatan pool of fund approach atau assets allocation. Pada metode pool of fund, semua dana BMT yang bersumber dari berbagai pihak dengan berbagai macam akad dikumpulkan kedalam satu wadah, kemudia manajemen BMT

\footnotetext{
${ }^{19} \mathrm{Ibid}$, Muchdarsyah Sinungan, hlm: 96.
} 
bebas mengalokasikan kedalam berbagai bentuk pembiayaan yang tidak dibatasi oleh model-model akad yang berbeda-beda baik akad yang memiliki hasil maupun tidak.

Selain itu, karena jumlah anggota BMT yang banyak, dengan anggota yang mayoritas pedagang kecil, petani dan mayoritas beragama Islam, mereka tidak mempermasalahkan dana mereka dikelola memakai metode apapun, sehingga BMT lebih mudah dan jauh lebih leluasa dalam mengelola dananya. Adapun pengelolaan dana BMT adalah sebagai berikut:

\section{a. Penghimpunan Dana BMT}

1) Giro.

Giro adalah simpanan pihak ketiga pada bank yang penarikanya dapat dilakukan setiap saat dengan mempergunakan cek, surat perintah, pembayaran lainya atau dengan cara pemindah bukuan. Dalam hal ini, BMT Mubarakah tidak memiliki sumber dana dalam bentuk giro.

2) Tabungan.

Tabungan adalah salah satu bentuk simpanan pihak ketiga pada bank. Simpanan ini penarikanya hanya dapat dilakukan menurut syarat-syarat tertentu yang telah ditetapkan.

3) Deposito.

Deposito atau bisa disebut dengan simpanan berjangka, sumber dana yang kedua ini adalah simpanan pihak ketiga yang penarikanya hanya dapat dilakukan dalam jangka waktu tertentu menurut perjanjian.

4) Modal sendiri.

Sumber dana yang dimiliki BMT yang terakhir adalah Modal sendiri.

\section{b. Pengelolaan Atau Pengalokasian Dana Pada BMT}

Dana yang dihimpun dari masyarakat dalam bentuk tabungan maupun deposito BMT tersebut akan menjadi beban apa bila dibiarkan begitu saja tanpa ada alokasi untuk tujuan-tujuan produktif. Dana yang dihimpun dari masyarakat dalam bentuk tabungan dan deposito atau dana pihak ketiga lainya bukanlah dana yang semuanya murah karena dapat menimbulakn kewajiban bagi BMT untuk membayar imbal balik jasa selain itu juga untuk memperoleh penerimaan BMT dalam rangka menutup biaya-biaya lain serta mendapatkan keuntungan. Maka dari itu BMT harus berusaha mengalokasikan dananya dalam bentuk aktiva antara lain:

1) Cadangan likuiditas.

Aktiva ini ditunjukkan untuk memenuhi likuiditas jangka pendek.Resiko dari aktiva ini tergolong rendah dan BMT tidak dapat terlalu mengharapkan adanya 
penerimaan dalam jumlah yang tinggi dari aktiva ini. Cadangan likuiditas ini terdiri dari dua kategori yaitu:

Cadangan primer

Cadangan ini biasanya dalam bentuk kas, saldo pada bank lain dan warkat dalam proses penagihan. Aktiva ini ditunjukkan terutama untuk memenuhi reserve requirement yang ditentukan oleh BMT dan juga untuk kegiatan sehari- hari seperti penarikan dana oleh nasabah, penyelesaian kliring, untuk membayar gaji karyawan membayar pajak, melunasi hutang dan membayar deviden.

Cadangan sekunder

Cadangan sekunder ini biasanya dalam bentuk surat berharga jangka pendek yang mudah dijual belikan, Surat Berharga Pasar Uang, Sertifikat Bank Indonesia, Surat Utang Negara Dan Sertifikat Deposito.

2) Kredit.

Kredit merupakan kesepakatan kedua belah pihak untuk saling memberi dan menerima sesuatu dimana pada saat tertentu pihak penerima harus membayar pokok dang anti rugi (opportunity cost) atas dana yang dipinjamnya.

3) Investasi.

Investasi adalah penanaman dana dalam bentuk surat berharga jangka menengah dan jangka panjang atau penyertaan langsung pada badan usaha lain. Bentuk dari surat berhaga tersebut antara lain adalah saham dan obligasi. Seperti halnya penyaluran kredit, karena rate of return dari aktiva ini relative tinggi atau dengan kata lain investasi ini tergolong aktiva produktif, maka aktiva ini juga mengandung resiko yang relatif besar.

4) Aktiva tetap.

Aktiva tetap merupakan aktiva yang tidak produktif dalam menghasilkan penerimaan oleh BMT. Dipandang sebagai aktiva yang mempunyai resiko yang cukup besar karena resiko ini dikaitkan dengan kemungkina rusak, terbakar bahkan hilangnya dari aktiva tetap. Oleh sebab itu, perlu dilakukan pembatasan penanaman dalam bentuk aktiva tetap ini. 
Contoh trade off antara likuiditas dan profitabilitas BMT Mubarakah akan tampak pada tabel di bawah ini.

Tabel 6

Tingkat Likuiditas BMT Mubarakah Tahun 2010-2013

\begin{tabular}{|c|c|c|c|c|c|c|c|}
\hline \multirow{2}{*}{ No } & \multirow{2}{*}{ Tahun } & \multicolumn{6}{|c|}{ Tingkat likuiditas } \\
\cline { 3 - 8 } & & \multicolumn{4}{|c|}{ Cash Ratio } & \multicolumn{3}{c|}{ Loan to debt ratio } \\
\cline { 3 - 8 } & & Rasio & Prosentase & Kriteria & Rasio & Prosentase & Kriteria \\
\hline 1 & 2010 & $44,63 \%$ & - & Cukup & $57,06 \%$ & - & Kurang \\
\hline 2 & 2011 & $48,20 \%$ & $3,57 \%$ & Kurang & $53,45 \%$ & $(3,61 \%)$ & Kurang \\
\hline 3 & 2012 & $41,20 \%$ & $(7,00 \%)$ & Cukup & $64,41 \%$ & $10,96 \%$ & Kurang \\
\hline 4 & 2013 & $43,38 \%$ & $2,18 \%$ & Cukup & $60,12 \%$ & $(4,29 \%)$ & Kurang \\
\hline
\end{tabular}

Sumber : Data sekunder yang diolah

Tabel 7

Tingkat Profitabilitas BMT Mubarokah 2010-2013

\begin{tabular}{|c|c|c|c|c|c|c|c|c|}
\hline \multicolumn{7}{|c|}{ Tingkat Profitabilitas } \\
\hline \multicolumn{7}{|c|}{ Return On Asset } & Rentabilitas Modal Sendiri & Kemandirian operasional \\
\hline Rasio & Prosentas & Kriteria & Rasio & Prosentas & kriteria & Rasio & prosentas & Kriteria \\
\hline $2,55 \%$ & - & Rendah & $3,98 \%$ & - & Rendah & 112,21 & - & Kurang \\
\hline $2,50 \%$ & $(0,05 \%)$ & Rendah & $3,75 \%$ & $(0,24 \%)$ & Rendah & 111,37 & $(0,48 \%)$ & Kurang \\
\hline $1,90 \%$ & $(0,06 \%)$ & Rendah & $4,01 \%$ & $0,28 \%$ & Rendah & 110,10 & $(1,63 \%)$ & Kurang \\
\hline $1,91 \%$ & $0,01 \%$ & Rendah & $4,51 \%$ & $0,50 \%$ & Rendah & 110,55 & $0,45 \%$ & Kurang \\
\hline
\end{tabular}

Sumber: Data sekunder yang diolah

Dari kedua tabel di atas dapat menunjukkan BMT Mubarakah mengalami fluktuasi tingkat likuiditas dan profitabilitas. Dalam trade offantara likuiditas dan profitabilitas BMT Mubarakah lebih mengutamakan tingkat likuiditasnya, hal ini dapat dilihat dari tingkat rasio likuiditas baik ditinjau dari cash ratiomaupun loan to deposit ratio.Kas ataupun alat pembayaran tunai lebih banyak yang menganggur dibandingkan dengan pembiayaan yang disalurkan kepada masyarakat. Banyaknya kas yang menganggur akan berpengaruh pada pengorbanan tingkat profitabilitas. Hal ini dapat dilihat pada tingkat profitabilitas yang rendah. 
BMT Mubarakah harus lebih cakap dalam mengelola dana guna menghasilkan keuntungan yang tinggi dan tetap dapat membayar penarikan yang diminta oleh nasabah sewaktu-waktu. Selain itu kinerja marketing BMT Mubarakah harus lebih dimaksimalkan untuk menarik masyarakat atau nasabah untuk melakukan pembiayaan, sehingga dapat menghasilkan laba dan kas yang menganggur tidak terlau banyak, BMT Mubarakah perlu memiliki marketing strategi yang baik.

\section{G. Kesimpulan.}

Berdasarkan pembahasan sebelumnya, maka dapat ditarik kesimpulan sebagai berikut :

1. Dari tahun 2010 hingga 2013 tingkat likuiditas ditinjau dari cash ratio rata-rata masuk dalam kategori cukup likuid kecuali tahun 2011 menjadi kurang likuid. Dari tingkat rasio di atas menunjukkan BMT Mubarakah terlalu banyak menyimpan dana, sehingga terjadi idle. Hal tersebut dapat dilihat dari tingkat rasio yaitu 44,60\% (2010), 48,20\% (2011), 41,20\% (2013) dan 43,38\% (2013) padahal tingkat likuiditas yang menunjukkan kategori likuid hanya sebesar 26-34\%. Semakin banyak kas yang menganggur akan menimbulkan pengorbanan pada profitabilitas. Pada tahun 2010 sampai 2013 tingkat likuiditas ditinjau dari Loan To Debposit Ratio masuk dalam kategori kurang likuid walaupun pada tahun 2012 mengalami peningkatan. Tingkat likuiditas sebesar 57,06\% (2010), 53,45\% (2011), 64,41\% (2012) dan 60,12\% (2013). Hal ini menunjukkan kinerja marketing dalam menyalurkan pembiayaan belum maksimal, dana kas menanggur lebih banyak.

2. Tingkat profitabilitas ditinjau dari Return On Assetdari tahun 2010 - 2013 masuk dalam kategori rendah yaitu 2,55\% (2010), 2,50\% (2011), 1,90\% (2012), $1,91 \%$ (2013). Ditinjau dari rasio rentabilitas modal sendiri masuk dalam kategori rendah pula yaitu di bawah <5\% yaitu 3,98\% (2010), 3,75\% (2011), 4,01\% (2012), 4,51\% (2013). Dan ditinjau dari rasio kemandirian operasional tingkat profitabilitas BMT Mubarakah dari tahun 2010-2013 masuk dalam kategori kurang profit yaitu 112,21\% (2010), 111.37\% (2011), 110,10\% (2012) dan $110,55 \%$ (2013). Rendahnya tingkat profitabilitas ini salah satunya disebabkan karena tingginya tingkat likuiditas.

3. Dalam pengelolaan dana likuiditas dan profitabilitas, BMT dapat menggunakan manajemen dengan pendekatan pool of fund approach. Semua dana BMT yang bersumber dari berbagai pihak dengan berbagai macam akad dikumpulkan kedalam satu wadah, kemudia manajemen BMT bebas mengalokasikan kedalam berbagai bentuk pembiayaan yang tidak dibatasi oleh model-model akad yang 
berbeda-beda baik akad yang memiliki hasil maupun tidak. Dalam trade off antara likuiditas dan profitabilitas BMT lebih mengutamakan tingkat likuiditasnya. Kas ataupun alat pembayaran tunai lebih banyak yang menganggur dibandingkan dengan pembiayaan yang disalurkan kepada masyarakat. Banyaknya kas yang menganggur akan berpengaruh pada pengorbanan tingkat profitabilitas. Hal ini dapat dilihat pada tingkat profitabilitas yang rendah.

\section{H. Saran.}

BMT harus lebih cakap dalam mengelola dana guna menghasilkan keuntungan yang tinggi dan tetap dapat membayar penarikan yang diminta oleh nasabah sewaktuwaktu. Selain itu kinerja marketing BMT harus lebih dimaksimalkan untuk menarik masyarakat atau nasabah untuk untuk melakukan pembiayaan, sehingga dapat menghasilkan laba dan kas yang menganggur tidak terlau banyak, BMT perlu memiliki marketing strategy yang baik. 


\section{DAFTAR PUSTAKA}

Ahmad Hasan Ridwan, Manajemen Baitul Mal wa Tamwil, Bandung; CV PUSTAKA SETIA, 2013

Cholid Narbuko dan H. Abu Achmadi, Metodologi Penelitian, PT. Bumi Aksara, Jakarta, 2009.

Deddy Mulyana, Metodologi Penelitian Kualitatif (Paradigma Baru Ilmu Komunikasi dan Ilmu Sosial Lainnya), PT Remaja Rosdakarya, Bandung, 2004

Herman Darmawi, Manajemen Perbankkan, Bumi Aksara, cetakan ke-1, Jakarta, 2011

Husain Usman dan Purnomo satiady Akbar, Metodologi PenelitIan Sosial, PT.Bumi Aksara, Jakarta, 2004.

Ivan Rohmawan, Kamus Istilah Akuntansi Syariah, Nuansa Aksara, Yogyakarta, 2005,

M. Suhan \& Ely Siswanto, Manajemen Bank Konvensional \& Syariah, UIN Malang Press (Anggota IKAPI), Malang, 2008

M.sulhan \& Ely Siswanto, Manajemen Bank Konvensional ESyariah, UIN-Malang Press (Anggota IKAPI), Malang, 2008

Mahmud M.Hanafi, Abdul Halim, Analisis Laporan Keuangan, UPP,STIM YKPN, Yogyakarta, 2007

Mahmud, Metode Penelitian Pendidikan, CV Pustaka Setia, Bandung, 2011

Muchdarsyah Sinungan, Manajemen Dana Bank Edisi ke-2, PT. Bumi Aksara, Jakarta, 2000

Muchdarsyah Sinungan, Strategi Manajemen Bank Menghadapi Tahun 2000, PT. RINEKA CIPTA, Jakarta, 1994

Muhammad Syafi'I Antonio, Bank Syariah Dari Teori Ke Praktek, Gema Insani Press, Jakarta, 2001

Muhammad, Manajemen Dana Bank Syariah, EKONOSIA, Yogyakarta, 2004

Mukhamad Saekan, Metodologi Penelitian Kualitatif, Nora Media Enterprise, Kudus, 2010

Munawir, Analisis Laporan Keuangan, Yogyakarta; Liberty, 2012

Noeng muhadjir, Metode Penelitian Kualitatif, Rake Sarasin, Yogyakarta, 1996

Peraturan Menteri Negara Koperasi Dan Usaha Kecil Dan Menengah Republik Indonesia Nomor : 35.3/Per/M.KUKM/X/2007 Tentang Pedoman Penilaian Kesehatan Koperasi jasa keuangan syariah dan unit jasa keuangan syariah koperasi.

Rimsky K. Judiseno, Sistem Moneter Dan Perbankan Di Indonesia, PT. Gramedia Pustaka Utama,, Jakarta, 2002

S. Nasution, Metode Research (Penelitian Ilmiah), Bumi Aksara, Jakarta, 2003 
Saifudin Anwar, Metode Penelitian, Pustaka Pelajar, Yogyakarta, 1997

Siti Amaroh, Manajemen Keuangan (Buku Daros), Kudus, 2008

Subagyo, Bank dan Lembaga Keungan Lainya, Edisi ke-2, Cetakan Pertama, Sekolah Tinggi Ilmu Ekonomi YKPN, Yogyakarta, 2002

Sugiyono, Memahami Penelitian Kualitatif, Alfa Beta, Bandung, 2005

Sugiyono, Metode Penelitian Pendidikan (Pendekatan Kuantitatif, Kualitatif, dan RED), Alfabeta, cv, Bandung, 2012 